\title{
Animal Studies Journal
}

Volume 9 | Number 1

Article 8

2020

\section{The Grieving Kangaroo Photograph Revisited}

David Brooks

University of Sydney

Follow this and additional works at: https://ro.uow.edu.au/asj

Part of the Agricultural and Resource Economics Commons, Art and Design Commons, Art Practice Commons, Australian Studies Commons, Communication Commons, Creative Writing Commons, Digital Humanities Commons, Education Commons, English Language and Literature Commons, Feminist, Gender, and Sexuality Studies Commons, Film and Media Studies Commons, Fine Arts Commons, Legal Studies Commons, Linguistics Commons, Philosophy Commons, Political Science Commons, Public Health Commons, Race, Ethnicity and Post-Colonial Studies Commons, Sociology Commons, and the Theatre and Performance Studies Commons

\section{Recommended Citation}

Brooks, David, The Grieving Kangaroo Photograph Revisited, Animal Studies Journal, 9(1), 2020, 201-215.

Available at:https://ro.uow.edu.au/asj/vol9/iss1/8

Research Online is the open access institutional repository for the University of Wollongong. For further information contact the UOW Library: research-pubs@uow.edu.au 


\title{
The Grieving Kangaroo Photograph Revisited
}

\begin{abstract}
Early in 2016 a photograph circulated widely of a male kangaroo holding up a dying female in the presence of a joey. Although initially taken as a moving and powerful photograph of grief, 'experts' quickly determined that this male may have killed the female in the process of coition. The male was in effect accused and convicted of rape and murder. Was this judgement correct? Was the male innocent or guilty? What are the nature, strength and politics of the assumptions involved in this judgement? Might he be exonerated, and why should this matter? The photograph is read and contextualised. A brief is assembled in his defence.
\end{abstract}

\section{Keywords}

kangaroo, grief, anthropomorphism, exoneration, media, representation 


\section{The Grieving Kangaroo Photograph Revisited}

\section{David Brooks}

\section{University of Sydney}

Abstract: Early in 2016 a photograph circulated widely of a male kangaroo holding up a dying female in the presence of a joey. Although initially taken as a moving and powerful photograph of grief, 'experts' quickly determined that this male may have killed the female in the process of coition. The male was in effect accused and convicted of rape and murder. Was this judgement correct? Was the male innocent or guilty? What are the nature, strength and politics of the assumptions involved in this judgement? Might he be exonerated, and why should this matter? The photograph is read and contextualised. A brief is assembled in his defence.

Keywords: kangaroo, grief, anthropomorphism, exoneration, media, representation

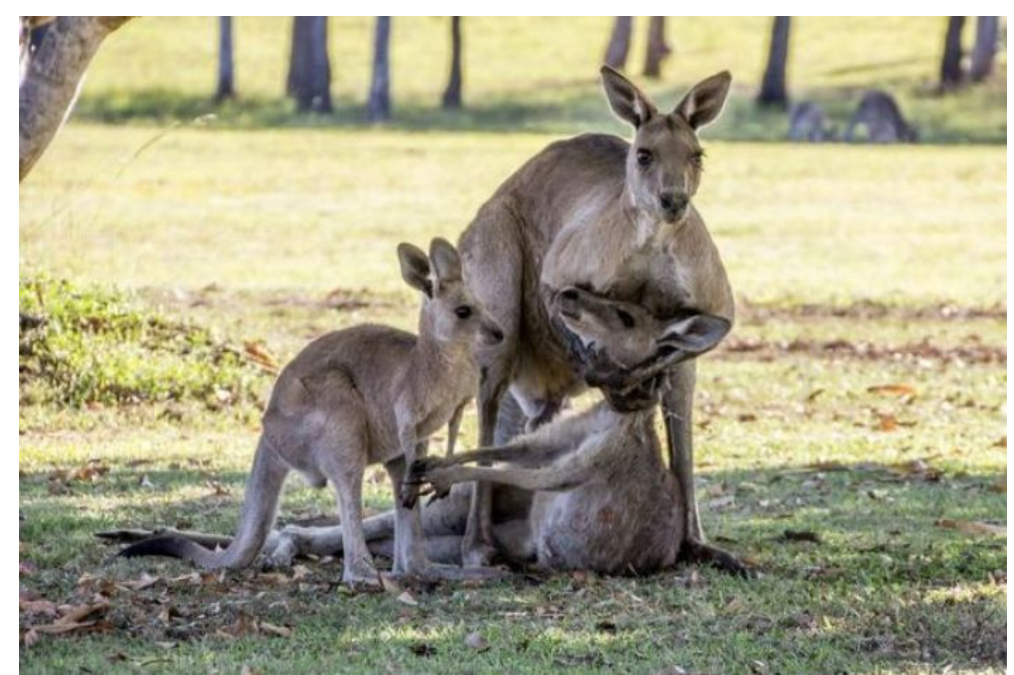

Fig. 1. The Grieving Kangaroo. Photo: Evan Switzer 
On January $13^{\mathrm{TH}}$, 2016, the Fraser Coast Chronicle, a small Queensland newspaper, published an item by Amy Formosa entitled 'Photographer captures kangaroo family’s grief'. The accompanying photos, taken two days before, 'went viral', and were viewed around the world.

One image in particular stood out: an adult male cradling the head of a dying doe lifting her, or so it appeared, so she could look more directly at a joey standing before her (fig. 1). Her arms, in this photograph, stretch out as if to catch the joey's forepaws one last time. It is hard not to think of this as a family. It seems, contrary to what we're told of mob structure (a dominant male, 'servicing' all does), as if this buck is the doe's partner and the joey their child. Grief and bewilderment - the pain of loss - well from the picture. I imagine it was shared so widely because of what people recognised in it, an emotion that crossed the species barrier.

The photographer was Evan Switzer, and the photographs were taken in open parkland at River Heads, Queensland, a coastal settlement 300 kilometres north of Brisbane. It's impossible from this photograph to tell why the doe is dying, indeed even that she is dying: she may in fact be dead already. Switzer says he could see no signs of injury, but River Heads is a popular departure-point for Fraser Island and there are cars about. One strong possibility - the photographs convey the sense this death has been sudden - is that she's been hit by a car and sustained fatal internal injuries. Often such injuries are not readily apparent to an onlooker.

We might leave it there - a powerful image, or set of images (a total of six were eventually released), offering a glimpse into the human-like emotional life of a non-human being; something that, as such epiphanies can do, brings us somehow closer to those beings, and them to us, suggests a kind of common ground. But I'm not sure we can leave it there. Even the image of a dying kangaroo, it seems, is political.

It's unclear whether the Chronicle took these photographs to an expert, or simply reported on that person's independent response, but the next day, hot on its heels, came another piece, entitled 'The Ugly Truth about that “Grieving Roo” Photograph' (Emery), conveying the opinion of a man I'll call 'Dr E', emphatically dismissing the initial interpretation of the image. 
By this time, the Chronicle piece had been picked up internationally. The Daily Mail and The Guardian carried versions on January $14^{\text {th }}$, as did The Washington Post and many other newspapers.

It appears that one of these syndicating papers - perhaps The Guardian but these things can be hard to track - had then approached an expert of their own, from a reputable Australian university. Almost immediately, in any case, the Guardian published its own retraction (Hunt). 'Dr [S],' it began, 'a senior lecturer in veterinary pathology, says it is "gross misunderstanding” to think [the] kangaroo was cradling [a] dying mate'. 'The photographs', Hunt explains, 'showed the male kangaroo "mate guarding" - holding other males at bay':

'Competition between males to mate with females can be fierce and can end in serious fighting,' [Dr S.] said. 'It can also cause severe harassment and even physical abuse of the target female, particularly when she is unresponsive or tries to get away from [an] amorous male. ...[I]nterpreting the male's actions as being based on care for the welfare of the female or the joey is a gross misunderstanding, so much so that the male might have actually caused the death of the female.'

Dr S, the article continues, 'added that, though he thought the term was often misunderstood and misused, the reporting of the viral photographs had been "naive anthropomorphism"”.

'Naïve anthropomorphism'. Count to ten, when talk of an animal's emotions is concerned, and, like the proverbial bad penny, anthropomorphism turns up.

Defined by the Oxford English Dictionary as 'the attribution of human personality or characteristics to something non-human, as an animal, object, etc.', anthropomorphism has long been employed to criticise those who argue for the presence of human-like emotions and emotional intelligence in non-human beings, with the implication that such attribution is a kind of intellectual embarrassment, a naïveté to the point where a term like 'naïve anthropomorphism' becomes virtually tautological. From an animalist perspective, on the other hand, the accusation of anthropomorphism can only appear as a means of hosing down any sparks of empathy and identification with non-human animals before the species barrier begins to smoulder. ${ }^{1}$ 
This isn't to say there's no such thing as naïve anthropomorphism. As with many of our concepts, from 'the survival of the fittest', say, to 'deconstruction', there can be useful, sophisticated and comprehending forms, and simplistic and naïve ones. People will dress their cats and dogs in human costumes, insist their tortoises have opinions about television programs, etc. - i.e. will force a demotic humanness onto non-human animals in a manner that demeans non-human and human animals alike - but blaming anthropomorphism per se for such naïveté is itself an intellectual error.

'The kangaroo's “sinister” intentions', The Guardian continued, reverting to the expert quoted by the Chronicle, were first suggested by Dr E of the Australian Museum, who said the photographs had been 'fundamentally misinterpreted'. 'This', he said, 'is a male trying to get a female to stand up so he can mate with her':

He pointed to the 'highly stressed and agitated' state of the male kangaroo, which had been licking its forearms to cool down. [He] also pointed to 'evidence ... sticking out from behind the scrotum' of the kangaroo's sexual arousal.

If the original piece presenting the photograph as of a grieving kangaroo went viral, the 'revelation' of its 'misinterpretation' spread even more rapidly. From a grieving partner, the buck became, overnight, a 'sinister' killer (The Washington Post actually spoke of necrophilia). Search 'grieving kangaroo' even now and you'll find many more pieces gloating over the gullibility of those believing the buck was grieving than accounts suggesting he was actually doing so ('No, this Kangaroo Wasn't Grieving - It Was Raping a Dead Female’ [Readhead]; ‘Grieving Kangaroo Actually Just Wants Sex' [Xinhua, P.R.C.]; ““Grieving” Kangaroo Photos May Actually Show Brutal Murder Scene' [Seleh]; etc.). We've been hoodwinked if we think this apparently tender, traumatised kangaroo is anything other than ('the "ugly" truth') a sexually over-charged male frustrated at having (shades of René Descartes: the non-human animal as machine) busted his toy before he could have his way with it.

Whether we see this as trial by sensationalist media or by a public responding to fodder that media had served them, the buck had in effect been charged with and, unrepresented and on the slimmest of evidence, found guilty of a heinous crime. If one reflects, with sad irony, that such travesties of justice are often called 'Kangaroo' courts, one reflects just as ruefully upon the 
alarm and denial with which so many view any opening of the door to animal emotions - a door which, opening, exposes the extent of human cruelty and their own unwitting participation in it - and the vicious pleasure they take in slamming it shut.

Is there any way the buck might be exonerated? Where would one begin? The 'experts' have certainly stacked the cards against him.

Tempting as it might be, for example, in a time of widespread and indisputably justified condemnation of abuse by rogue human males, to turn the accusation of anthropomorphism back on the scientists and suggest that even their own supposed objectivity might reflect and unwittingly exploit some very topical human preoccupations, I think we need to do some further thinking here. Dr E draws our attention to parts of the image most viewers won't have noticed. Is he correct in his interpretation? Should we now pack away, embarrassedly, our felt connection with this (as we thought) family group, or is there more to the issue?

Kangaroos (for example) are thickly supplied with veins on their forearms, close to the skin's surface, and cool themselves, on hot days, by licking that surface (and that of their legs, belly, tail). While it may be true, as Dr E points out, that the fact the buck has been licking his forearms is an indication he's 'hot and bothered', he doesn't mention that on the humid midsummer Monday upon which these photographs were taken the temperature in River Heads was 30 degrees in the shade, warm enough for any kangaroo to have been licking his/her forearms to cool down. Nor does he mention that the joey, too, has been licking his forearms. Must we think of him, also, as part of this supposed sexual arousal and aggression, toward his own mother?

To do Dr E justice, it's true that in some of these photographs one glimpses the male kangaroo's erect penis - a more reliable indication of arousal than licked forearms - but of what, if anything, is this conclusive? Chimpanzees in a zoo masturbate when excited or distressed; elephant males can develop erections when distressed; human males, when stressed or anxious, can experience unwarranted erections; the penis of the kangaroo male 'is extended erect while eating' (Staker 2), and, preparing to write this essay, I've found several photographs of kangaroo males, in what I call the 'guard' position, with erections (fig. 2). 


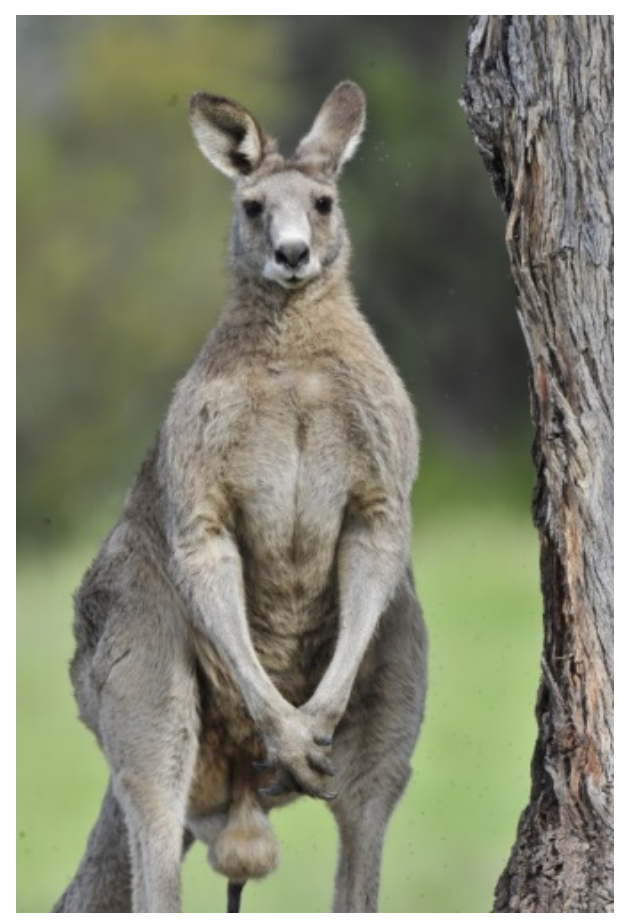

Fig. 2. Buck kangaroo in guard position. Photo: Ray Drew

Still, although it doesn't seem to me the presence of an erection, in such a stressed and distressing situation, must necessarily be a sign of sexual arousal, we can't dismiss the possibility. Must we even then, however, interpret it as Dr E suggests? What do we know of the inner workings of a kangaroo's psyche? I can think of at least one play by Shakespeare (Othello) in which sexual excitement, murder, and what some might think of as love are deeply confused in the one person and moment. And I imagine I'm not alone as, reading yet another of the Australian Broadcasting Commission's all-too frequent reports of a domestic homicide, I sometimes find myself wondering whether some such lethal cocktail might have been involved.

Let's nevertheless entertain Dr E's hypothesis that the buck might have accidentally killed the doe in the process of a sexual encounter. Would even that mean he could not be dismayed, horrified or confused by what has happened - that he cannot grieve? Why would even this most extreme case mean that, as these experts say so emphatically, this is not a photograph of a grieving kangaroo? 
There are, moreover, three kangaroos in the photograph. The doe, if not dead already, is dying, and in this extremis may well be experiencing her own form of grief, as is (I think we can surmise) the joey. To say that, because it may be that the buck may not be grieving in the unalloyed, uncomplicated manner in which people first looking at the photograph might have assumed, this photograph is not a photograph of a grieving kangaroo, is quite a stretch (and a tad chauvinistic).

Why - a second reservation - must we normalise grief, and then impose that grief-model upon non-human animals, if only in the negative form of denying their capacity for it? Humans themselves do not have the one consistent mode of grieving. There are people who place their deceased in vats until all juices have leached out. There are people who sleep with their deceased partners until the rotting flesh drops from their bones (Metcalf and Huntington, Celebrations of Death 56, 64). Zoroastrian grief accommodates placing the dead on especially-constructed platforms to be eaten by vultures. Why must we deny non-human animals grief-modes of their own? Isn't it just possible, for example, that this male kangaroo feels that sex with his partner might actually revive her? In denying him unknown alternatives of motivation, and imposing only those they know, aren't the 'experts' providing us, ironically (and yet again), with an example of the self-same anthropomorphism of which they accuse others?

Roland Barthes (Camera Lucida 27) speaks of the punctum of a photograph, that detail which at once jumps out at us and centres the image somehow, not only commencing and guiding our 'reading' of that photograph, but making us want to read in the first place.

The concept can be applied more broadly. At a time when the kangaroo, as a set of tribes amongst us, is so widely and cruelly persecuted, the very state of its race a grieving, this photograph itself could be seen as the punctum of a much larger picture. Day after day, night after night, in almost all parts of the country, kangaroos are being shot or run down, their families, mob structures and cultures devastated, to the point, in some areas, of regional extinction. Accept the grief in this photograph, as such, and we court a vast and devastating realisation, might find it hard to keep a that greater grief at bay.

Is the punctum of this photograph the eyes of the buck, looking directly at us, his face with its complex expression of alarm, bewilderment and deepening sadness? Is it, instead, his 
paws about the neck of the doe as, in one interpretation, he holds her head up to see her son one last time or, in the other, grasps her in attempted possession? Is it her arms, reaching out, as they do seem to do, to her joey? The answer may vary from viewer to viewer. It may even change as one's reading develops.

For me, the extended arms of the doe come close, or rather the paws. Or did, initially. That it's both of them, just touching those of the joey, and - although one knows this may just be rigor mortis, an indication she's been dead an hour or more - that they're so tense, every digit stretched to its maximum, as if in a last, anxious effort. ${ }^{2}$ Though I'd not have dismissed the two kangaroos grazing in the distance, for the emptiness they seem to emphasise. The 'experts', who insist this is not a photograph of grief but of a male clutching, in a manner designed to ward off other males, a female he may just have killed in the process of coition - have they taken this emptiness into account? Where are the competing males? If, as the photographer, interviewed for the first Chronicle piece, does indicate, there were other males close by at some point, and this buck chased them off, they don't seem to have returned. Certainly, they're not in any of these photographs.

I'm embarrassed to think how long it took me to contemplate the legs of the doe. Was I dramatically underestimating the foreshortening caused by the perspective, or was I right, at last, in thinking her right leg, the lower part of which was angled, awkwardly, directly toward the viewer, had been distorted somehow, perhaps even severed somewhere above the last joint? Even if it was just foreshortening, and she was quite intact, the angle of that last section - her foot - seemed exaggerated, as if her leg had been badly broken or was being held in an unnatural position.

So far, to be as fair as possible to those I felt to have cruelly and hastily condemned the buck, I'd worked only with the materials publicly available, and refrained from any attempt to contact the photographer. It was only now I felt I could and perhaps should do so. Although it seemed to me there must be a leg injury, no amount of enlargement and close examination of the photographs available could confirm it. The buck was still not in the clear. Switzer is on record as having stated he could see no signs of physical injury upon the doe. I needed to find out how closely he'd been able to examine her, and whether there was any chance he'd missed something. 
In a telephone conversation on 5 October 2018, while repeating he'd seen no injury, Switzer told me he'd been able to approach her only once, to check her pouch at a point where the buck and joey were standing off at a little distance, and that, while he did so, he'd been too concerned watching the buck (who, it must be said, would almost certainly have attacked, if he had been sexually aroused; the buck's restraint here seems to me quite significant) to check the rest of her, and so could neither confirm nor rule out a leg injury. To aid my thinking, and on the chance there might be one that showed an injury more clearly, he sent me his full set of just over two hundred photographs, all taken in the eighty minutes from 4.36 until 5.56 p.m. on the day in question.

Although difficult to quantify exactly, the buck, in these photographs, lifts or attempts to lift the doe's head and shoulders between thirteen and sixteen times. He has an erection in several of these attempts, but, significantly, there's no evidence (at least not that I can find), in any of the images, of attempted intercourse. Instead most of these attempts to lift her could be seen as attempts to hold, and perhaps rub, her head against his chest.

'Chesting' is a common behaviour in Eastern Grey kangaroos. The kangaroo chest contains powerful scent glands. These are used to mark territory, although the question of marking raises the issue of the complex and ambiguous relations between endearment, attachment, and possession. The buck's attempt to rub his scent onto the doe - if this is what it is, rather than simply to hold her close - may be as much to protect her (or her body) from the encroachments of other males as to establish her as his territory, i.e. may be a matter of affection/attachment rather than maintenance of position. Curiously, although we might expect it in a sexually aroused male, very few photographs (there are some) show the buck sniffing at or paying any particular attention to the doe's hind quarters/cloacal area.

Considerable attention, on the other hand - seen in seventeen photos - is paid to her ears, and in a dozen more such close attention is paid to her face and mouth one might almost construe it as kissing.

Overall, the weight of this extended sequence seems more on the side of grief and endearment than attempted coitus, the erect penis rather, and as already suggested, an indication of distress than sexual intent. All very well, but this buck has also been accused, if not 
of actual murder, then of the kangaroo equivalent of manslaughter. Only unambiguous evidence of an alternate cause of death can begin to absolve him of this. Do we have it?

At first I thought not. The vast majority of these photographs are taken from the same position as five of the six already published, and therefore show the same foreshortening of the right leg without in any way clarifying the cause of that distortion. There is one, however, in which the buck, attempting to roll the doe onto her back, exposes her right leg quite clearly (fig. 3). The ankle, in this photograph, appears badly swollen and out of alignment, and the leg at this point unnaturally bent, in contrast to the stiffened and outstretched left leg.

My knowledge of macropod anatomy is limited. I sent both the full photograph in which the leg's shape clearly appears, and an enlargement of the ankle itself (fig. 4), to two very experienced wildlife rescuers, each of whom has an intimate day-to-day knowledge of kangaroos.

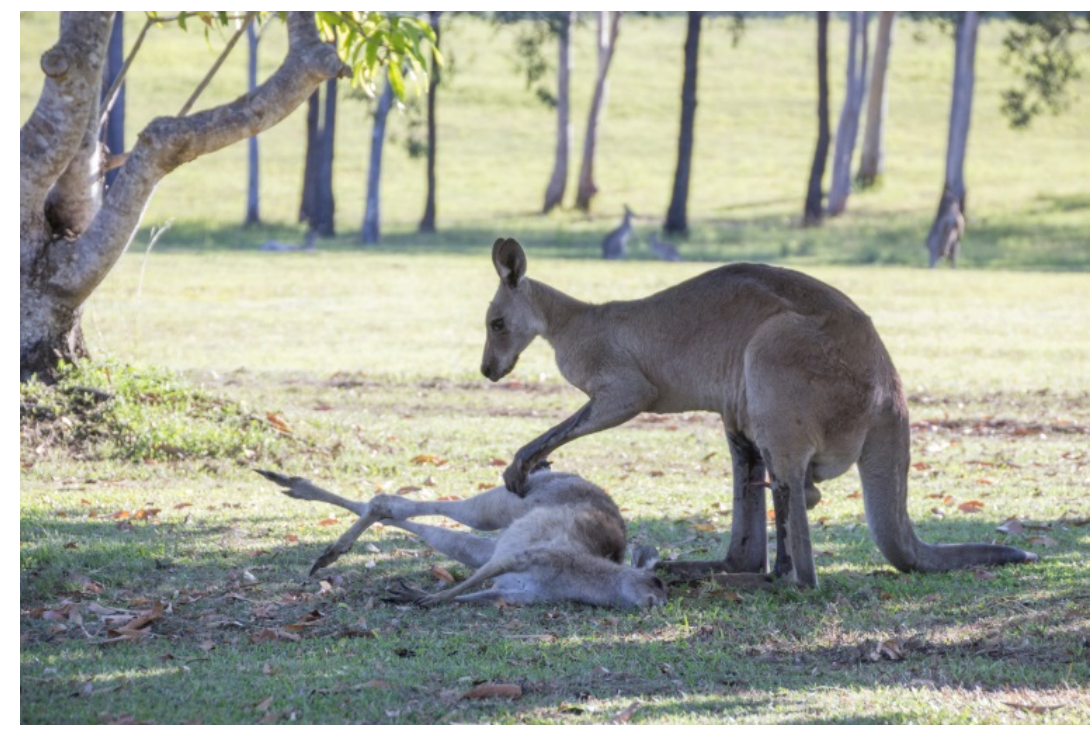

Fig. 3. View of the doe on her side. Photo: Evan Switzer 


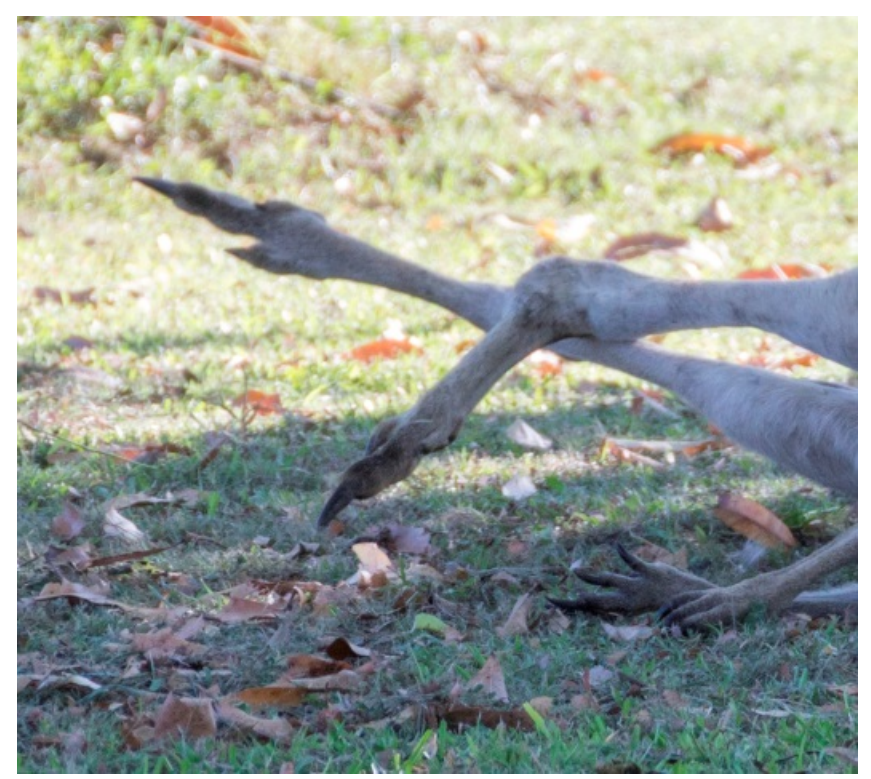

Fig. 4. Enlargement of the ankle. Photo: Evan Switzer

Each confirmed that the doe had a displaced fracture of the right ankle. Each suggested (something of which I'd made no mention) the most likely cause of her death was that she'd been hit by a car. I then asked one of them whether there were any scent glands in or near the kangaroo's ear, since the buck had been paying the doe's ears such attention. He said he was unaware of any scent glands there, but that roos who were close to one another would often groom one another's ears.

Death, then, from a combination of external and internal injuries, most likely caused by a collision with a motor vehicle. Can I say, with absolute certainty, that there's been no 'rape' of a dead female, that this isn't a 'brutal murder scene', or that the buck has not 'just wanted sex'? No, of course not, though if the buck 'just wanted sex' I can't imagine he'd have hung around so long and so fruitlessly. My strong sense, however, is that he's not guilty of any of these things, and that, if there's been any bestiality here, it's been in the viewers, not the viewed - that a significant injustice has been done to him and, through him, to his species, and that we owe them extensive redress.

There is more to say on this matter, much more, and greater detail to be offered on almost all points raised, but I will leave that for another piece. ${ }^{3}$ The final images in the sequence 
show the buck alone with the doe, now clutching her to his chest, now laying her down, now picking her up again, unable to leave, unable to stop holding (fig. 5). The shadows are lengthening. The roos who were grazing in the distance have moved on. The joey has wandered out of frame. Ungrounded, or so it would seem to me, utterly lost, the buck, in the very last of them, looks off and downward at something that may not be there at all. The eyes of the doe, if we look closely enough - through the camera lens, through the years, through whatever barriers we might try to put up against them - are staring directly at us.

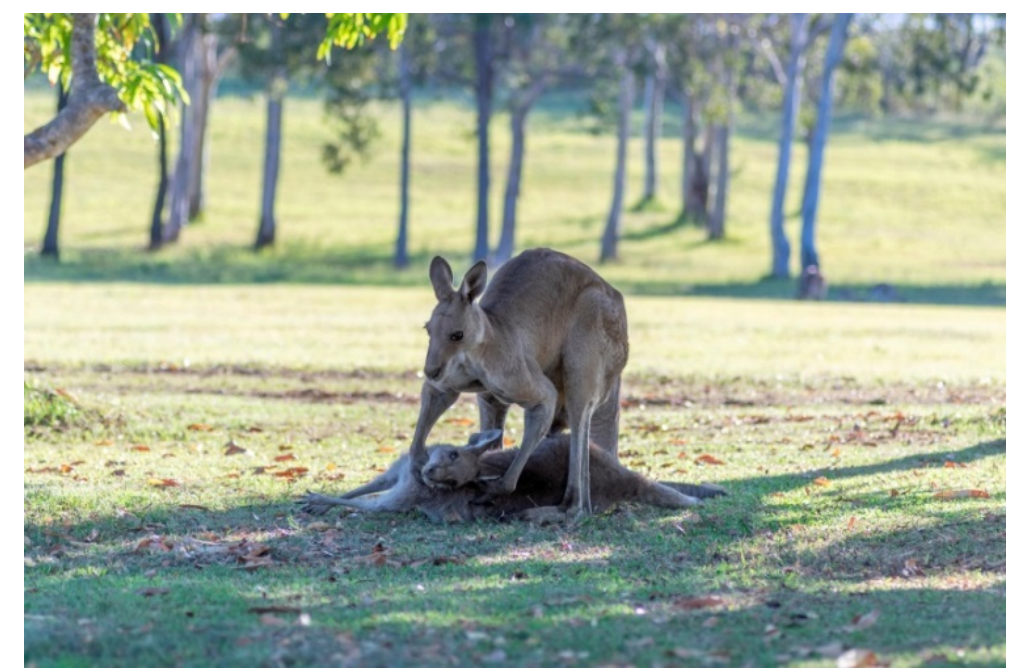

Fig. 5: The buck remains with the body. Photo: Evan Switzer 


\section{Notes}

1 'Anthropomorphism', I've argued elsewhere, 'is central to what we call empathy, and since empathy is fundamental to compassion, in the denial of anthropomorphism is that repression of empathy which is fundamental to the horrific abuse of animals which has always scarred this civilization (and almost every other civilization I can think of)' (The Grass Library 26).

${ }^{2}$ One reader has suggested that, as in dogs and cats, these stiffened limbs may simply be a reflex response to being picked up, though in dogs and cats this would seem a response to being lifted from the ground by the body or under the arms, neither of which is the case here. That the doe's arms appear to come together at those of the joey might indicate volition. The wind, I think, blows both ways.

3 'An Exoneration', in David Brooks, Animal Dreams, forthcoming from Sydney University Press. 


\section{Works Cited}

Barthes, R. Camera Lucida, translated by R. Howard, Hill \& Wang, 1981.

Brooks, D. The Grass Library. Brandl \& Schlesinger, 2019.

Emery, L. 'The Ugly Truth about that “Grieving Roo” Photograph.' Fraser Coast Chronicle, 14 Jan. 2016. https: / / www.frasercoastchronicle.com.au/news/what-was-roo-reallydoing/2899125/

Feltman, R. 'Photos of "Grieving” Kangaroo Actually Show Necrophilia (and Possibly a Killing)'. The Washington Post, 15 Jan. 2016.

https: / / www.washingtonpost.com/news/speaking-ofscience/wp/2016/01/14/photos-of-grieving-kangaroo-actually-show-necrophilia-andpossibly-a-killing/

Formosa, A. 'Photographer Captures Kangaroo Family's Grief'. Fraser Coast Chronicle, 13 Jan. 2016. https: / /www.frasercoastchronicle.com.au/news/his-heart-skipped-a-beat/2897351/

Hunt, E. 'Kangaroo in “Grieving” Photos May Have Killed while Trying to Mate, Scientist Says'. The Guardian, 14 Jan. 2016.

https: / / www.theguardian.com/science/2016/jan/14/photos-grieving-kangaroo-viralbut-scientist-says-sexually-aroused

Metcalf, P. and R. Huntington. Celebrations of Death: The Anthropology of Mortuary Ritual. Cambridge University Press, 1979.

Readhead, H. 'No, this Kangaroo Wasn't Grieving - It Was Raping a Dead Female.' Metro News, 14 Jan. 2016. https: / / metro.co.uk/2016/01/14/no-this-kangaroo-wasnt-grieving-itwas-raping-a-dead-female-experts-say-5623631/

Seleh, P. “'Grieving” Kangaroo Photos May Actually Show Brutal Murder Scene.' The Daily Wire, 15 Jan. 2016. https://www.dailywire.com/news/update-grieving-kangaroophotos-may-actually-show-pardes-seleh 
Staker, L. Macropod Husbandry, Healthcare and Medicinals, vol. 1, 2014.

[Xinhua] 'Grieving Kangaroo Actually Just Wants Sex’. Xinhua, 15 Jan. 2016.

http: / /www.china.org.cn/environment/2016-01/15/content_37582758.htm

\section{Acknowledgements}

With thanks to Evan Switzer for his conversation and permission to use hitherto unpublished photographs, to Ray Drew, and to Prof. Steven Garlick, Stella Reid and Ray Mjadwesche for assistance in the preparation of this essay. 